\title{
Research on the impact of innovation input on enterprise performance in manufacturing enterprises--- Moderating effect based on governance structure
}

\author{
QianYu Zhao ${ }^{1 *}$, Gang Fu², and WanTing $\mathrm{Liu}^{3}$ \\ ${ }^{1}$ QianYu Zhao, Sichuan Agricultural University,611130,Chengdu,China \\ ${ }^{2} \mathrm{Gang} \mathrm{Fu}$, Sichuan Finance and Economics Vocational College, 611130, Chengdu, China \\ ${ }^{3}$ WanTing Liu, Sichuan Agricultural University,611130,Chengdu,China
}

\begin{abstract}
Manufacturing industry is the lifeblood of national economy, and innovation input is the lifeline of manufacturing enterprises. This paper selects the financial data of China's listed manufacturing companies from 2015 to 2019 to study the moderating effect of governance structure on the relationship between innovation input and firm performance. It is found that innovation investment has a negative influence on firm performance with lag. In terms of ownership structure, ownership concentration has a negative moderating effect on the relationship between innovation input and firm performance. The degree of equity balance has a positive moderating effect on the relationship between innovation input and firm performance. According to the conclusion of this study, it is expected to optimize the governance structure of China's manufacturing enterprises and promote industrial development.
\end{abstract}

\section{The Introduction}

Manufacturing industry has always been in the leading position in the national economy, is the lifeblood of the national economy,is also the backbone of China's industrialization process. However,the development of manufacturing industry has encountered a bottleneck in recent years, facing many crises and challenges. For example,high labor costs, excessive tax burden, overcapacity and other problems.To improve business performance and gain competitive advantage in the market,manufacturing enterprises not only need to improve their own innovation and research ability,but also a good governance structure is an important link to improve performance.

The contributions of this paper are as follows :(1) The moderating effect of the governance structure of listed manufacturing firms on the relationship between ${ }^{1}$ innovation input and firm performance is explored by using hierarchical regression and grouping regression methods. (2) Divide into groups according to the nature of property rights,and further explore the differences between state-owned holding and non-state-owned holding enterprises.(3)Using principal component analysis to construct comprehensive indicators to evaluate enterprise performance can more comprehensively reflect the operating ability of the enterprise.The aim is to improve the governance structure of Chinese manufacturing enterprises,optimize the allocation of enterprise resources, and correct the inefficient investment in innovation.

\section{Theoretical analysis and research hypothesis}

\subsection{The impact of innovation input on firm performance}

Enterprise innovation input is not only beneficial to improve the production efficiency and business performance of enterprises, but also helpful to improve the core competitiveness of enterprises.However,the

\footnotetext{
1'QianYu Zhao:544046490@qq.com

${ }^{2}$ Gang Fu:583900556@qq.com

${ }^{3}$ WanTing Liu:2464678922@qq.com
} 
innovation input has the characteristics of highly asymmetric information, strong uncertainty,long cycle, lagging returns,etc,which is particularly significant in manufacturing enterprises.It may take many operating years for innovation investment to generate financial returns. Manufacturing enterprises, on the other hand, at the time of innovation investment, are likely to be higher in the research stage and development stage to produce the cost of spending on research and development, management in order to pursue their tenure bring enterprise economic returns, pay more attention to shortterm interests,may to a certain extent restrict enterprises innovation investment, not conducive to the long-term development of enterprises in the future.Therefore,the following hypotheses are proposed:

$\mathrm{H}_{1}$ : Innovation input has a negative lag effect on enterprise performance.

\subsection{The moderating effect of ownership structure on innovation input and firm performance}

\subsubsection{The moderating effect of ownership concentration on innovation input and firm performance}

In manufacturing enterprises, the phenomenon of "one dominant" still exists. With a high degree of ownership concentration, many small and medium investors may be harmed by controlling shareholders (Halla, 2006) ${ }^{[1]}$. The investment in innovation is accompanied by high risk, long cycle and slow effect, which may lead to the situation of unrecoverable costs and huge losses for enterprises.Company executives pay more attention to short-term interests, fail to allocate resources reasonably and effectively,and lack consideration for long-term interests of the enterprise(Danmeng, 2008) ${ }^{[2]}$.Large shareholders will reduce investment in enterprise innovation activities for the avoidance of risks.High concentration and low dispersion of enterprise ownership will lead to risk concentration, which will inhibit enterprise innovation investment.Therefore,the following hypotheses are proposed:

$\mathrm{H}_{2}$ :Ownership concentration has a negative moderating effect on the relationship between innovation input and firm performance.

\subsubsection{The moderating effect of equity balance on innovation input and firm performance.}

Equity decentralization alleviates the "encroachment effect" of major shareholders, and the higher degree of equity checks and balances is conducive to mutual supervision among shareholders to avoid damaging the interests of minority shareholders and to improve business performance of enterprises (Gomes, 2001) ${ }^{[3]}$. The higher the degree of equity checks and balances, the higher the supervisory role of external shareholders, and the less likely minority shareholders are to be infringed (Pagano $M, 1998)^{[4]}$.Equity checks and balances can make the major shareholders contain each other,and the small and medium shareholders can get more discourse power. The role of equity balance is conducive to the formation of a good operation mechanism and governance structure inside the enterprise, which helps the management to make effective innovation investment decisions and improve the performance of the enterprise.Therefore, the following hypotheses are proposed:

$\mathrm{H}_{3}$ :The degree of equity balance has a positive moderating effect on the relationship between innovation input and firm performance.

\section{The research methods}

\subsection{Sample selection and data sources}

This paper selects the financial data of listed manufacturing companies in China from 2015 to 2019 , excluding *ST and ST companies. In the end, 6,700 observations were obtained, including 1,860 state-owned ones and 4,840 non-state-owned ones.

\subsection{Variable selection}

\subsubsection{Explained variables}

In order to more comprehensively measure the business operation level of the enterprise,In this paper, 13 indicators are selected from debt-paying ability,profitability, operation ability and growth ability to build a comprehensive evaluation system. The comprehensive performance evaluation index of the enterprise is determined as the explained variable, as shown in Table 1:

Table1 Evaluation system of enterprise performance comprehensive indicators

\begin{tabular}{|c|c|}
\hline Evaluation of Angle & Name \\
\hline \multirow{4}{*}{ Debt paying ability } & Asset-liability ratio \\
\cline { 2 - 2 } & Quick ratio \\
\cline { 2 - 2 } Profitability & Cash ratio \\
\cline { 2 - 2 } & Return on total assets \\
\cline { 2 - 2 } & Return on assets \\
\cline { 2 - 2 } Operation ability & Earnings per share \\
\hline \multirow{4}{*}{ Accounts receivable } \\
turnover
\end{tabular}

Using principal component analysis to determine the comprehensive performance evaluation index, $\mathrm{K}$ value is $0.705>0.5, \mathrm{P}$ value is 0 ,through the significance test, can be done principal component analysis. KMO and Bartlett tests are shown in Table 2: 
Table $2 \mathrm{KMO}$ and Bartlett tests

\begin{tabular}{|c|c|c|}
\hline \multicolumn{2}{|c|}{$\begin{array}{r}\text { Sampling the Kaiser-Meyer-Olkin } \\
\text { measure of adequacy }\end{array}$} & 0.705 \\
\hline \multirow{3}{*}{$\begin{array}{c}\text { Bartlett's test for } \\
\text { sphericity }\end{array}$} & $\begin{array}{c}\text { The approximate } \\
\text { chi-square }\end{array}$ & 44448.343 \\
\cline { 2 - 3 } & $\mathrm{df}$ & 78 \\
\cline { 2 - 3 } & Sig. & .000 \\
\hline
\end{tabular}

\subsubsection{Explanatory variables}

Referring to (JianrongTang, 2014) ${ }^{[5]}$, this paper uses the ratio of $R \& D$ investment to operating income to measure the intensity of enterprise's innovation investment.

Table 3 Variable selection and definition

\begin{tabular}{|c|c|c|c|}
\hline Variable & $\begin{array}{l}\text { Variable } \\
\text { name }\end{array}$ & Symbol & $\begin{array}{c}\text { Variable } \\
\text { declaration }\end{array}$ \\
\hline $\begin{array}{l}\text { Explained } \\
\text { variable }\end{array}$ & $\begin{array}{l}\text { Enterprise } \\
\text { performance }\end{array}$ & PER & $\begin{array}{l}\text { Integrated } \\
\text { computation }\end{array}$ \\
\hline $\begin{array}{c}\text { Explanatory } \\
\text { variables }\end{array}$ & Innovation & $\mathrm{RD}$ & $\begin{array}{l}\text { Investment/ } \\
\text { revenue }\end{array}$ \\
\hline & $\begin{array}{l}\text { Ownership } \\
\text { concentration }\end{array}$ & $\mathrm{C} 1$ & $\begin{array}{l}\text { Shareholding } \\
\text { ratio of the } \\
\text { largest } \\
\text { shareholder }\end{array}$ \\
\hline $\begin{array}{l}\text { Adjust } \\
\text { variable }\end{array}$ & $\begin{array}{l}\text { Equity } \\
\text { balance }\end{array}$ & $\mathrm{ZH}$ & $\begin{array}{c}\text { The } 2 \text { to } 10 \\
\text { largest } \\
\text { shareholder } \\
\text { shareholding } \\
\text { ratio/the largest } \\
\text { shareholder } \\
\text { shareholding } \\
\text { ratio }\end{array}$ \\
\hline \multirow{5}{*}{$\begin{array}{c}\text { Control } \\
\text { variables }\end{array}$} & Growth & Growth & $\begin{array}{c}\text { Change in } \\
\text { operating } \\
\text { income/operating } \\
\text { income }\end{array}$ \\
\hline & $\begin{array}{l}\text { Company } \\
\text { size }\end{array}$ & Size & $\begin{array}{l}\text { The natural log } \\
\text { of total assets }\end{array}$ \\
\hline & $\begin{array}{c}\text { Asset- } \\
\text { liability ratio }\end{array}$ & Lev & $\begin{array}{c}\text { Total } \\
\text { liabilities/total } \\
\text { assets } \\
\end{array}$ \\
\hline & $\begin{array}{c}\text { Enterprise } \\
\text { age }\end{array}$ & Age & $\begin{array}{c}\text { Year of } \\
\text { observation - } \\
\text { year of } \\
\text { establishment }\end{array}$ \\
\hline & Year & Year & $\begin{array}{c}\text { Dummy } \\
\text { variable, } \mathrm{j} \text { year } \\
\text { is } 1 \text {, otherwise } 0\end{array}$ \\
\hline
\end{tabular}

\subsection{Model building}

Building a regression model.Introducing adjusting variable Character $_{i, t}$ including ownership concentration $\left(C 1_{i t}\right)$, Equity balance $\left(Z H_{i t}\right)$.

$P E R_{i t}=\alpha+\beta_{1} R D_{i, t-n}+\Sigma \beta_{j}$ Control $_{i t}+\varepsilon_{i t}$

$P E R_{i t}=\alpha+\beta_{1} R D_{i, t}+\beta_{2}$ Character $_{i, t}+\Sigma \beta_{j}$ Control $_{i t}+\varepsilon_{i t}$

$$
\begin{gathered}
P E R_{i t}=\alpha+\beta_{1} R D_{i, t}+\beta_{2} \text { Character }_{i, t}+\beta_{3} R D_{i, t} \times \\
\text { Character }_{i, t}+\Sigma \beta_{j} \text { Control }_{i t}+\varepsilon_{i t}
\end{gathered}
$$

Control $_{i t}$ represents the Control variable, i $\mathrm{t}$ represents the $t$ year of enterprise $(n=0,1,2), \alpha$ is the intercept term, and $\varepsilon$ is the random disturbance term.

\section{The empirical analysis}

\subsection{The impact of innovation input on firm performance}

As you can see from Table 4,PER and $R D 、 R D_{t-1}$ 、 $R D_{t-2}$, the correlation coefficients were $-0.106,-0.080$ and -0.079 .All passed the significance test at the $1 \%$ level, and the negative influence showed a decreasing trend year by year.There is a significant lag negative effect between innovation input and firm performance. $\mathrm{H}_{1}$ is verified.

Table 4 Regression results of innovation input and enterprise

\begin{tabular}{|c|c|c|c|}
\hline Variable & Model 1 & Lag phase I & Lag phase II \\
\hline$R D$ & $\begin{array}{c}-0.106 * * * \\
(-8.734)\end{array}$ & & \\
\hline$R D_{t-1}$ & & $\begin{array}{c}-0.080 * * * \\
(-6.597)\end{array}$ & \\
\hline$R D_{t-2}$ & & & $\begin{array}{c}-0.079 * * * \\
(-6.519)\end{array}$ \\
\hline Growth & $\begin{array}{c}0.229 * * * \\
(19.191)\end{array}$ & $\begin{array}{c}0.241 * * * \\
(20.067)\end{array}$ & $\begin{array}{c}0.243 * * * \\
(20.213)\end{array}$ \\
\hline Size & $\begin{array}{c}0.148 * * * \\
(10.214)\end{array}$ & $\begin{array}{c}0.148 * * * \\
(10.139)\end{array}$ & $\begin{array}{c}0.148 * * * \\
(10.140)\end{array}$ \\
\hline Lev & $\begin{array}{c}-0.194 * * * \\
(-14.069)\end{array}$ & $\begin{array}{c}-0.190 * * * \\
(-13.760)\end{array}$ & $\begin{array}{c}-0.189 * * * \\
(-13.735)\end{array}$ \\
\hline Age & $\begin{array}{c}0.027 * * \\
(2.046)\end{array}$ & $\begin{array}{c}0.033 * * * \\
(2.469)\end{array}$ & $\begin{array}{c}0.034 * * \\
(2.553)\end{array}$ \\
\hline Year & control & control & control \\
\hline $\mathrm{N}$ & 6700 & 6700 & 6700 \\
\hline cons & $\begin{array}{c}-3.214 * * * \\
(-7.866) \\
\end{array}$ & $\begin{array}{c}-3.288 * * * \\
(-8.011)\end{array}$ & $\begin{array}{l}-3.223 * * * \\
(-7.908)\end{array}$ \\
\hline $\mathrm{F}$ & $83.467 * * *$ & $79.464 * * *$ & $79.339 * * *$ \\
\hline $\operatorname{Adj}-R^{2}$ & 0.100 & 0.095 & 0.095 \\
\hline
\end{tabular}
performance

Note: $* * *, * *, *$ indicate significant at $1 \%, 5 \%$ and $10 \%$ levels respectively, the same as below

\subsection{Regression analysis of the moderating effect of ownership concentration on innovation input and firm performance}

Firstly, the Model 2 and Model 3 were used to conduct the population regression for the whole sample, and then the grouping regression was performed according to the nature of the controlling person.It can be seen from Table 5 that the interaction coefficient of $\mathrm{C} 1$ and RD is -0.072 , which is significantly negative, indicating that ownership concentration has a negative regulating effect on innovation input and enterprise performance. The negative regulating effect in state-owned holding enterprises is significantly higher than that in non-state-owned holding 
enterprises. $\mathrm{H}_{2}$ is verified.

Table 5 Regression results of ownership concentration, innovation input and firm performance

\begin{tabular}{|c|c|c|c|c|}
\hline $\begin{array}{c}\text { Vari } \\
\text { able }\end{array}$ & $\begin{array}{c}\text { All the } \\
\text { samples }\end{array}$ & $\begin{array}{c}\text { All the } \\
\text { samples }\end{array}$ & $\begin{array}{c}\text { State } \\
\text { holding }\end{array}$ & $\begin{array}{c}\text { Non-state } \\
\text { holding }\end{array}$ \\
\cline { 2 - 5 } & Model2 & Model 3 & Model 3 & Model 3 \\
\hline RD & $\begin{array}{c}-0.099^{* * *} \\
(-8.157)\end{array}$ & $\begin{array}{c}-0.038 \\
(-1.289)\end{array}$ & $\begin{array}{c}0.007 \\
(0.098)\end{array}$ & $\begin{array}{c}-0.067 * * \\
(-2.047)\end{array}$ \\
\hline C1 & $0.069^{* * *}$ & $0.102^{* * *}$ & $0.095^{* * *}$ & $0.093^{* * *}$ \\
& $(5.814)$ & $(5.483)$ & $(2.564)$ & $(4.241)$ \\
\hline C1* & & $-0.072^{* * *}$ & $-0.153^{* *}$ & $-0.027 * *$ \\
RD & & $(-2.317)$ & $(-2.210)$ & $(-0.761)$ \\
\hline Gro & $0.231^{* * *}$ & $0.232^{* * *}$ & $0.182^{* * *}$ & $0.264 * * *$ \\
wth & $(19.401)$ & $(19.457)$ & $(8.006)$ & $(18.942)$ \\
\hline Size & $0.134 * * *$ & $0.132^{* * *}$ & $0.098^{* * *}$ & $0.146^{* * *}$ \\
& $(9.179)$ & $(9.004)$ & $(3.693)$ & $(8.740)$ \\
\hline Lev & $-0.190^{* * *}$ & $-0.190^{* * *}$ & $-0.138^{* * *}$ & $-0.216^{* * *}$ \\
& $(-13.859)$ & $(-13.835)$ & $(-5.395)$ & $(-13.709)$ \\
\hline Age & $0.034 * * *$ & $0.034 * *$ & 0.008 & 0.011 \\
& $(2.602)$ & $(2.549)$ & $(0.333)$ & $(0.722)$ \\
\hline Year & control & control & control & control \\
\hline $\mathrm{N}$ & 6700 & 6700 & 1860 & 4840 \\
\hline cons & $-3.096^{* *}$ & $-3.223 * * *$ & $-2.360^{* * *}$ & $-3.501 * * *$ \\
& $(-7.586)$ & $(-7.908)$ & $(-2.825)$ & $(-7.430)$ \\
\hline F & $78.870^{* * *}$ & $72.235^{* * *}$ & $17.684 * * *$ & $62.921^{* * *}$ \\
\hline Adj- & 0.104 & 0.105 & 0.090 & 0.123 \\
$\mathrm{R}^{2}$ & & & & \\
\hline & & & & \\
\hline
\end{tabular}

\subsection{Regression analysis on the moderating effect of equity balance degree on innovation input and firm performance}

It can be seen from Table 6 that in the whole sample, the interaction coefficient of $\mathrm{ZH}$ and $\mathrm{RD}$ is 0.091 ,which is significantly positive,indicating that the degree of equity balance has a positive regulating effect on innovation input and enterprise performance.Good equity checks and balances can form an effective supervision mechanism inside an enterprise,alleviate the interest conflicts among shareholders and curb the insider control problem.In the grouping regression, the interaction term coefficient passes the significance test in non-state-owned enterprises. However,it is not significant in state-owned enterprises, which may be because the implementation effect of equity balance in non-state-owned enterprises is better,which is more in line with the characteristics of collective decisionmaking and can improve decision-making efficiency. $\mathrm{H}_{3}$ is verified.

Table 6 Regression results of equity balance degree, innovation input and enterprise performance

\begin{tabular}{|c|c|c|c|c|}
\hline $\begin{array}{c}\text { Vari } \\
\text { able }\end{array}$ & $\begin{array}{c}\text { All the } \\
\text { samples }\end{array}$ & $\begin{array}{c}\text { All the } \\
\text { samples }\end{array}$ & $\begin{array}{c}\text { State } \\
\text { holding }\end{array}$ & $\begin{array}{c}\text { Non-state } \\
\text { holding }\end{array}$ \\
\cline { 2 - 5 } & Model 2 & Model 3 & Model 3 & Model 3 \\
\hline RD & $-0.103^{* * *}$ & $-0.158^{* * *}$ & $-0.153^{* * *}$ & $-0.150^{* * *}$ \\
& $(-8.536)$ & $(-8.390)$ & $(-4.432)$ & $(-6.612)$ \\
\hline$Z H$ & $-0.043^{* * *}$ & $-0.096^{* * *}$ & $-0.064^{* * *}$ & $-0.088^{* * *}$ \\
& $(-3.628)$ & $(-5.238)$ & $(-1.864)$ & $(-4.073)$ \\
\hline RD $^{*}$ & & $0.091^{* * *}$ & 0.036 & $0.086^{* *}$ \\
\hline
\end{tabular}

\begin{tabular}{|c|c|c|c|c|}
\hline ZH & & $(3.790)$ & $(0.823)$ & $(3.010)$ \\
\hline Gro & $0.232^{* * *}$ & $0.233^{* * *}$ & $0.183^{* * *}$ & $0.265^{* * *}$ \\
wth & $(19.403)$ & $(19.492)$ & $(8.050)$ & $(18.988)$ \\
\hline Size & $0.149 * * *$ & $0.148^{* * *}$ & $\begin{array}{l}0.115^{* * *} \\
(4.458)\end{array}$ & $\begin{array}{c}0.156^{* * *} \\
(9.384)\end{array}$ \\
\hline Lev & $-0.195 * * *$ & $-0.195^{* * *}$ & $-0.145^{* * *}$ & $-0.221 * * *$ \\
& $(-14.195)$ & $(-14.178)$ & $(-5.669)$ & $(-14.049)$ \\
\hline Age & 0.021 & 0.018 & 0.001 & -0.008 \\
& $(1.552)$ & $(1.354)$ & $(0.022)$ & $(-0.531)$ \\
\hline Year & control & control & control & control \\
\hline N & 6700 & 6700 & 1860 & 4840 \\
\hline cons & $-3.134 * * *$ & $-2.998^{* * *}$ & $-2.244 * * *$ & $-3.288^{* * *}$ \\
& $(-7.666)$ & $(-7.312)$ & $(-2.693)$ & $(-6.948)$ \\
\hline F & $76.573 * * *$ & $71.057 * * *$ & $17.444 * * *$ & $61.117 * * *$ \\
\hline Adj- & 0.101 & 0.103 & 0.089 & 0.120 \\
R ${ }^{2}$ & & & & \\
\hline
\end{tabular}

\section{Research conclusions recommendations} and

\subsection{Research conclusions}

Based on China's a-share manufacturing listed companies during 2015-2019 financial data as sample,empirical analysis was carried out on the 6700 valid samples. Build multiple regression model, to investigate the moderating effect of governance structure on innovation input and firm performance. The empirical research has drawn the following conclusions:(1) Innovation input has a lag negative impact on enterprise performance, and may not bring benefits to enterprises in the short term. (2)In terms of ownership structure,ownership concentration has a negative moderating effect on the relationship between innovation input and firm performance; The degree of equity balance has a positive moderating effect on the relationship between the two.

\subsection{Recommendations}

The research of this paper is of great significance for Chinese manufacturing enterprises to optimize their governance structure, correct their inefficient investment in innovation input,and improve their innovation performance. (1)Enterprises should not only pay attention to the supply of resources invested in innovation,but also pay attention to the improvement of investment decisionmaking efficiency.(2)Establish a reasonable equity structure,strengthen the role of equity checks and balances, implement effective supervision mechanism for major shareholders, and improve the efficiency of investment decision-making of enterprises.

\section{References}

1.Halla B H,Oriani R.Does the market value R\&D investment by European firms? Evidence from a 
panel of manufacturing firms in France,German,and Italy[J].International Journal of Industrial Organization, 2006(24):971-993.

2.Li Danmeng,Xia Lijun.The nature of equity, institutional environment and R\&D intensity of listed companies[J].Journal of Finance and Economics,2008,34(04):94-104.

3.Gomes A, Novaes W. Sharing of control as a corporate governance mechanism[R].University of Pennsylvania Center for Analytic Research in Economics and Social Science (CARESS), 2001.

4.Pagano M, Roell A. The choice of stock ownership structure: Agency costs, monitoring and the decision to go public[J].Quarterly Journal of Economics, 1998(113):187-226.

5.Tang Jianrong, Li qing. A logical analysis of governance structure, R\&D investment and performance: A review of the role of government subsidies $[\mathrm{J}]$. Audit \& Economics Research, 2019(02):67-78. 